\title{
EFFECT OF NITROCARBURIZING ON SHAPE OF TITANIUM ALLOY PARTS (U)
}

\author{
E.A. Clark \\ Savannah River Technology Center \\ Equipment and Materials Technology Department \\ Materials Technology Section
}

September 27, 1993

\section{Westinghouse Savannah River Company \\ P. O. Box 616 \\ Aiken, SC 29802}

PREPARED FOR THE U.S. DEPARTMENT OF ENERGY UNDER CONTRACT DE-AC09-88SR18035 


\section{DISCLAIMER}

This report was prepared as an account of work sponsored by an agency of the United States Government. Neither the United States Government nor any agency thereof, nor any of their employees, makes any warranty, express or implied, or assumes any legal liability or responsibility for the accuracy, completeness, or usefulness of any information, apparatus, product, or process disclosed, or represents that its use would not infringe privately owned rights. Reference herein to any specific commercial product, process, or service by trade name, trademark, manufacturer, or otherwise does not necessarily constitute or imply its endorsement, recommendation, or favoring by the United States Government or any agency thereof. The views and opinions of authors expressed herein do not necessarily state or reflect those of the United States Government or any agency thereof. 
Keywords:

Near-net-shape casting

Complex 21

Nuclear Reconfiguration

Retention: Permanent

\title{
EFFECT OF NITROCARBURIZING ON SHAPE OF TITANIUM ALLOY PARTS (U)
}

\author{
E.A. Clark \\ Savannah River Technology Center \\ Equipment and Materials Technology Department \\ Materials Technology Section
}

Publication Date: 27 September 1993

D.T.Ranhim

D.T. Rankin, Authorized Derivative Classifier 
WSRC-TR-93-474

UNCLASSIFIED

EFFECT OF NITROCARBURIZING ON SHAPE OF TITANIUM ALLOY PARTS (U)

APPROVALS

Elliot a Clank 10/27/93

E. A. Clark, Author

Date

D. Them Rankin

$10 / 27 / 63$

D.T. Rankin, Responsible Manager

Date

Cony A. Bey

$10 / 27 / 93$

C.S. Burgess, Technical Reviewer

Date

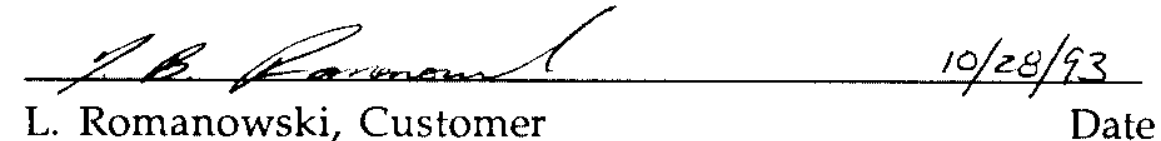

L. Romanowski, Customer

Date

ii 


\section{DISCLAIMER}

This report was prepared as an account of work sponsored by an agency of the United States Government. Neither the United States Government nor any agency thereof, nor any of their employees, makes any warranty, express or implied, or assumes any legal liability or responsibility for the accuracy, completeness, or usefulness of any information, apparatus, product, or process disclosed, or represents that its use would not infringe privately owned rights. Reference herein to any specific commercial product, process, or service by trade name, trademark, manufacturer, or otherwise does not necessarily constitute or imply its endorsement, recommendation, or favoring by the United States Government or any agency thereof. The views and opinions of authors expressed herein do not necessarily state or reflect those of the United States Government or any agency thereof.

This report has been reproduced directly from the best available copy.

Available to DOE and DOE contractors from the Office of Scientific and Technical Information, P. O. Box 62, Oak Ridge, TN 37831; prices available from (615) $576-8401$.

Available to the public from the National Technical Information Service, U. S. Department of Commerce, 5285 Pon Royal Rd., Springfield, VA 22161 



\section{Contents}

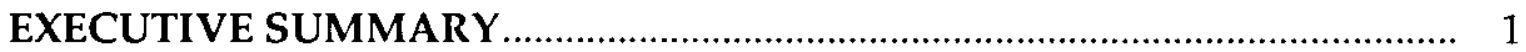

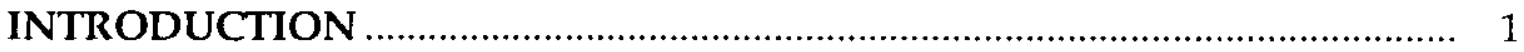

EXPERIMENTAL

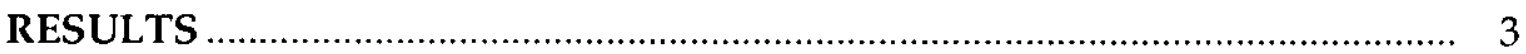

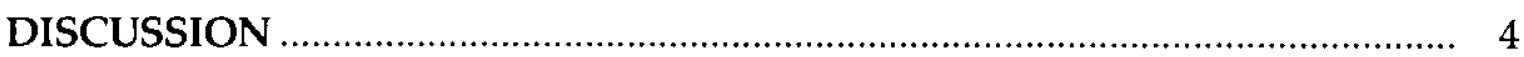

SUMMARY AND CONCLUSION ……………............................................

REFERENCES

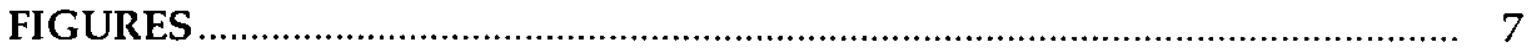


Figures

1. Measured thickness at four locations of as-received disk A and annealed disk B

2. Measured thickness at four locations of as-received disk C.

3. Measured maximum and minimum outside diameters of as-received disk 9 A and annealed disk B

4. Measured maximum and minimum outside diameters of as-received disk 10 C.

5. Measured flatness of both sides, in two orthogonal directions, of as-received disk $\mathrm{A}$ and annealed disk $\mathrm{B}$

6. Measured flatness of both sides, in two orthogonal directions, of as-received disk C.

7. Measured thickness at four locations of as-received ring $\mathrm{A}$ and annealed ring B.

8. Measured maximum and minimum outside diameters of as-received ring $A$ and annealed ring $B$.

9. Measured maximum and minimum inside diameters of as-received ring A 15 and annealed ring $B$.

10 a. Output of statistical analysis software JMP for this study.

$10 \mathrm{~b}$. Output of statistical analysis software JMP for this study.

11. Photograph of shot sleeve. 


\title{
EFFECT OF NITROCARBURIZING ON SHAPE OF TITANIUM ALLOY PARTS (U)
}

\author{
Elliot A. Clark
}

\section{EXECUTIVE SUMMARY}

The Equipment and Materials Technology Department is developing components for plutonium casting in support of Lawrence Livermore National Laboratory. A vendor used a proprietary process to grow a nitrocarburized surface layer on a titanium alloy shot sleeve that was to be used in a prototype die casting machine. The shot sleeve was significantly out-of-round upon return from the vendor, and could not be used. The purpose of this study was to determine whether the shape change could have been caused by this surface treatment.

Visual observation of disk and ring samples exposed first to the temperature of the surface treatment alone and then the actual nitrocarburizing environment revealed no indication of gross warping during either the thermal treatment or the nitrocarburization. Dimension measurements (for example thickness, diameter and flatness) of each sample before and after both the thermal treatment and the nitrocarburizing revealed no significant changes, within experimental accuracy. In addition, visual examination of the shot sleeve revealed a surface flaw that was likely made during handling after machining at SRS and before the part was nitrocarburized. The out-of-roundness of the shot sleeve could be related to the damage observed on the surface, but the possibility of warping during the nitrocarburizing cannot be excluded. Nitrocarburization should remain a candidate method to protect titanium alloys from molten metals.

\section{INTRODUCTION}

The Equipment Engineering Section (EES), Equipment and Materials Technology Department, Savannah River Technology Center, WSRC designed and built an advanced die casting machine. This prototype machine was used to partially evaluate advance die casting for production of precision parts, in support of programs lead by the Lawrence Livermore National Laboratory for the Nuclear Weapons Complex Reconfiguration program of the US Department of Energy. Titanium alloys served as materials of construction in the prototype die caster because of the combination of good strength and low density of these alloys. 
It was recognized that the titanium alloy surfaces that contact molten metal would require a surface coating, to protect the parts from liquid metal corrosion ${ }^{1}$. A promising proprietary process, the Dyna-Blue Process ${ }^{\mathrm{TM}}$ of Dynamic Metal Treating, Inc. ${ }^{2}$, was found that gave titanium-6\% aluminum- $4 \%$ vanadium (Ti-6-4) good resistance to molten metals in preliminary exposure tests ${ }^{1}$. This process exposes the surface to be coated to a controlled atmosphere and solids in a high-temperature fluidized bed. Stable thick (visible) films grow that contain a mixture of nitrogen and carbon ${ }^{1}$. The shot sleeve of the die caster was fabricated from titanium- $6 \%$ aluminum-2\% tin- $4 \%$ zirconium- 2\% molybdenum-0.08\% silicon (Ti-6242S) and sent to Dynamic Metal Treating for coating. Upon return, the piston no longer moved in the shot sleeve because the shot sleeve was significantly out-of-round. In addition, a mark was visible on the outside of the sleeve. This mark had been made before the part was coated since it was covered with the translucent blue-black film that covered the rest of the part.

This study was undertaken to determine whether the Dyna-Blue ${ }^{\mathrm{TM}}$ process itself could cause warping of wrought or annealed titanium alloys. Dynamic Metal Treating was contacted about the warping of the shot sleeve, and became interested in evaluating whether their Dyna-Blue ${ }^{\mathrm{TM}}$ process could cause distortion of titanium alloy parts. They claim to have successfully coated complex titanium alloy shapes for other customers, without warping these parts. They agreed to share the cost of investigating whether the exposure to the high temperature of the Dyna-Blue ${ }^{\mathrm{TM}}$ process alone could cause warping, or whether the full process could cause $\mathrm{it}^{3}$.

\section{EXPERIMENTAL}

The samples used for this study were in the form of either disks or rings as follows:

\begin{tabular}{|c|c|c|c|}
\hline $\begin{array}{c}\text { Sample } \\
\text { Designation }\end{array}$ & Material & Temper & History \\
\hline Disk A & Ti-6-4 & Hardened (as received) & Treated \\
\hline Disk B & Ti-6-4 & Annealed & Treated \\
\hline Disk C & Ti-6-4 & Hardened (as received) & Control \\
\hline Ring A & Ti-6242S & Hardened (as received) & Treated \\
\hline Ring B & Ti-6242S & Annealed & Treated \\
\hline
\end{tabular}


The disks were nominally 0.25 " thick, and had $2 "$ diameter, and the rings were nominally 0.25 " thick, and had an outside diameter of 2.75 " and an inside diameter of $1.75 "$.

The samples that were "Treated" were first exposed to the temperature cycle used in the Dyna-Blue ${ }^{\mathrm{TM}}$ process, except the exposure was performed in nitrogen gas. Later, the same parts underwent the Dyna-Blue ${ }^{\mathrm{TM}}$ process in the fluidized bed with a controlled atmosphere that grew a nitrocarburized surface film on the outside. Disk $\mathrm{C}$ was used as a control, and was exposed to neither the temperature exposure nor the Dyna-Blue ${ }^{\mathrm{TM}}$ process.

Various sample dimensions were measured by Site Services Quality/Quality Verification, Westinghouse Savannah River $\mathrm{Co}^{4}$. These dimensions were measured three times: i) before any treatment, ii) after thermal treatment, and iii) after DynaBlue $^{\mathrm{TM}}$ processing. Measurements of disk $\mathrm{C}$ were repeated each time the treated samples were measured. Dimensions measured on the disks were: thickness (four locations $90^{\circ}$ apart, and approximately $1 / 4^{\prime \prime}$ in from outer diameter), minimum and maximum outer diameter, and flatness (Total Indicator Reading, TIR). Dimensions measured on the rings were: thickness (four locations $90^{\circ}$ apart, and approximately $1 / 4$ " in from outer diameter), minimum and maximum outer diameter, and minimum and maximum inner diameter. Measurements were reported to an accuracy of $0.0001 "$ in all cases.

\section{RESULTS}

No significant dimension changes occurred for any of the samples because of either the thermal treatment or the Dyna-Blue ${ }^{\mathrm{TM}}$ process. The differences in measurements of the disk samples were comparable to differences found in repeated measurements of the control disk $\mathrm{C}$ at different times (compare Figs. 1 and 2, Figs. 3 and 4, and Figs. 5 and 6). Dimensional differences in the ring samples were similar to those of the disks(Figs. 7-9). Note the samples included two tempers (as-received \{disk A, ring A\} and annealed (disk B, ring $B$ \}) and two different materials (Ti-6-4 \{disk $A$ and disk $B$ \} and Ti-6242S (ring $A$ and ring $B$ )). Statistical analysis software ${ }^{5}$ also indicated no significant effect of either thermal treatment or Dyna-Blue ${ }^{\mathrm{TM}}$ processing on dimensional measurements of the samples studied (Figs. $10 a$ and $b$ ).

The population standard deviation of measurements at each location (taken as a group) varied between about 0.0005 " and 0.0015 " for all the samples, which is larger than the 
precision reported for each measurement $(0.0001 ")$. This is probably caused by not measuring at exactly the same location after each treatment. Because of this, only systematic changes of measured parameters greater than about $0.0015^{\prime \prime}$ could have been observed in this study, and none were observed. This does not rule out warping that causes smaller dimensional changes.

\section{DISCUSSION}

The observation of a flaw underneath the partially transparent blue-black Dyna-Blue ${ }^{\mathrm{TM}}$ film (Fig. 11) is evidence that the shot sleeve was damaged some time after machining at SRS and before being nitrocarburized. It is uncertain but possible that the force causing the surface damage could have caused the part to become out-of-round.

One effect of the Dyna-Blue ${ }^{\mathrm{TM}}$ process on titanium alloys that has been previously documented is that the microstructure anneals during the process ${ }^{1}$. Stress relieving and annealing causes parts to warp if they have significant residual stress. It is possible that the original shot sleeve was not completely stress relieved, although it was supposed to have been, and the shot sleeve subsequently warped while being coated. If the samples used for this study had lower residual stresses, no warping would be seen.

If the microstructure change during Dyna-Blue ${ }^{\mathrm{TM}}$ processing degrades the strength of the alloy below that acceptable for use, it may be necessary to investigate hardening the part by heat treatment after surface coating. This study would require experimental tests of surface coating followed by whatever heat treatment is applicable and effective for the specific alloy being used.

\section{SUMMARY AND CONCLUSION}

1) Ti-6-4 disk samples and Ti-6242S ring samples did not significantly warp or change dimension during the Dyna-Blue ${ }^{\mathrm{TM}}$ nitrocarburizing process of Dynamic Metal Treating, Inc., within experimental accuracy.

2) Visual observation of a Ti-6242S shot sleeve from a prototype die caster revealed that the part was damaged before undergoing the Dyna-Blue ${ }^{\mathrm{TM}}$ process. The shot sleeve was significantly out-of-round upon return from the vendor. Whether the surface damage is related to the out-of-roundness is unknown.

3) Dyna-Blue ${ }^{\mathrm{TM}}$ should remain a candidate surface coating method for titanium alloys exposed to molten plutonium. 


\section{ACKNOWLEDGMENTS}

The aid of V.L. Skidmore, and M.A. Atristain of WSRC and Ed Dryer of Dynamic Metal Treating, Inc. in completing this study is gratefully acknowledged. V.S. Owen photographed the shot sleeve. 


\section{REFERENCES}

1) E.A. Clark and M.A. Atristain. Molten Plutonium-Materials Compatibility Evaluation (U). USDOE Report WSRC-RP-92-1405, Westinghouse Savannah River Co., Aiken SC 29802 (July 16, 1993).

2) Dynamic Metal Treating, Inc., 7857 Ronda Dr, Canton Township, MI (313) 459-8022.

3) Procured under Purchase Order No. AB23013N, Westinghouse Savannah River Co.

4) Site Services Quality/Quality Verification Inspection Report numbers 92-IR-06-8437 (9/24/92), 93-IR-06-7201 (2/9/93), and 93-IR-06-7413 (6/7/93).

5) JMP version 1.0.6, SAS Institute, Box 8000, Cary, NC 27512 (1989). 
Disk A- As Received

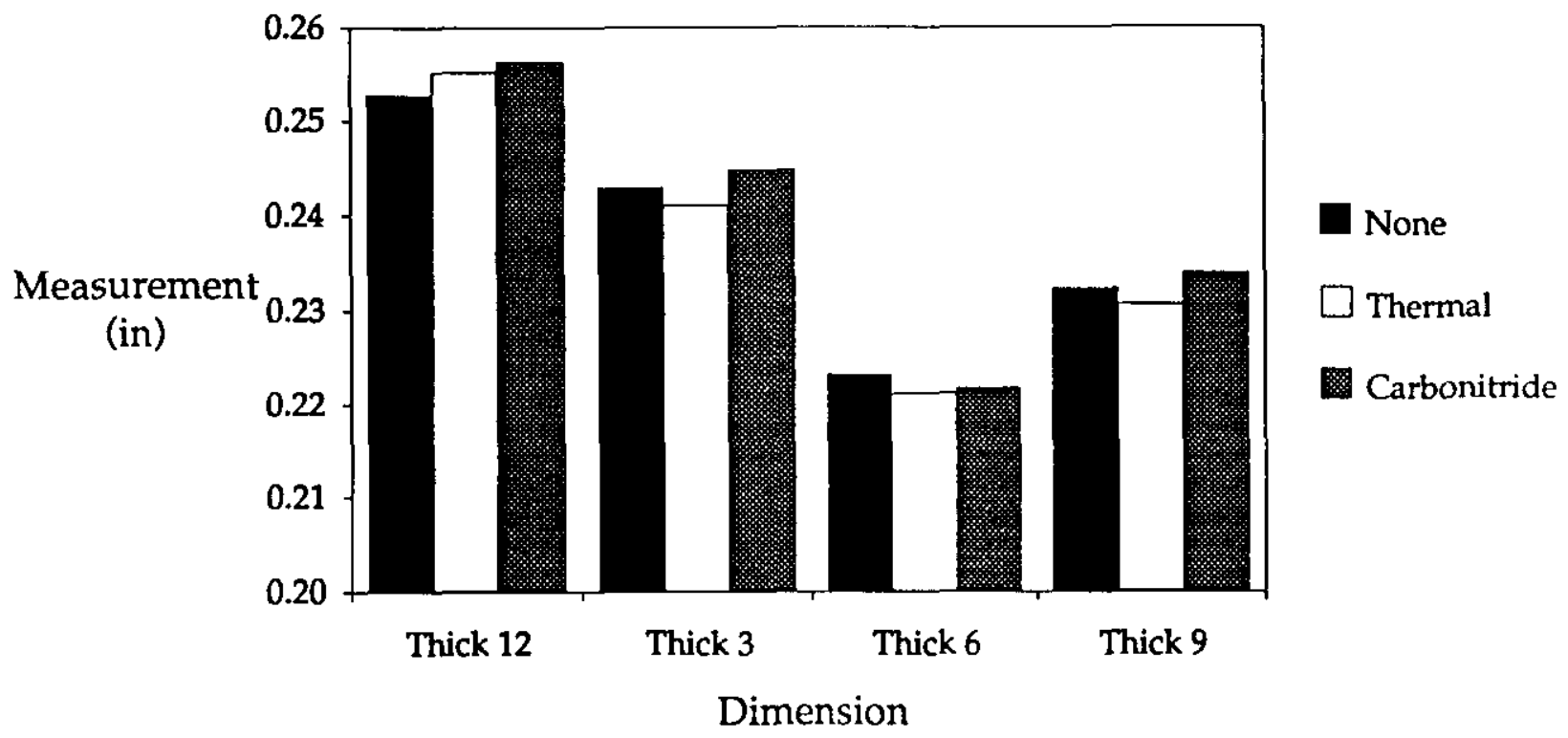

Disk B- Annealed

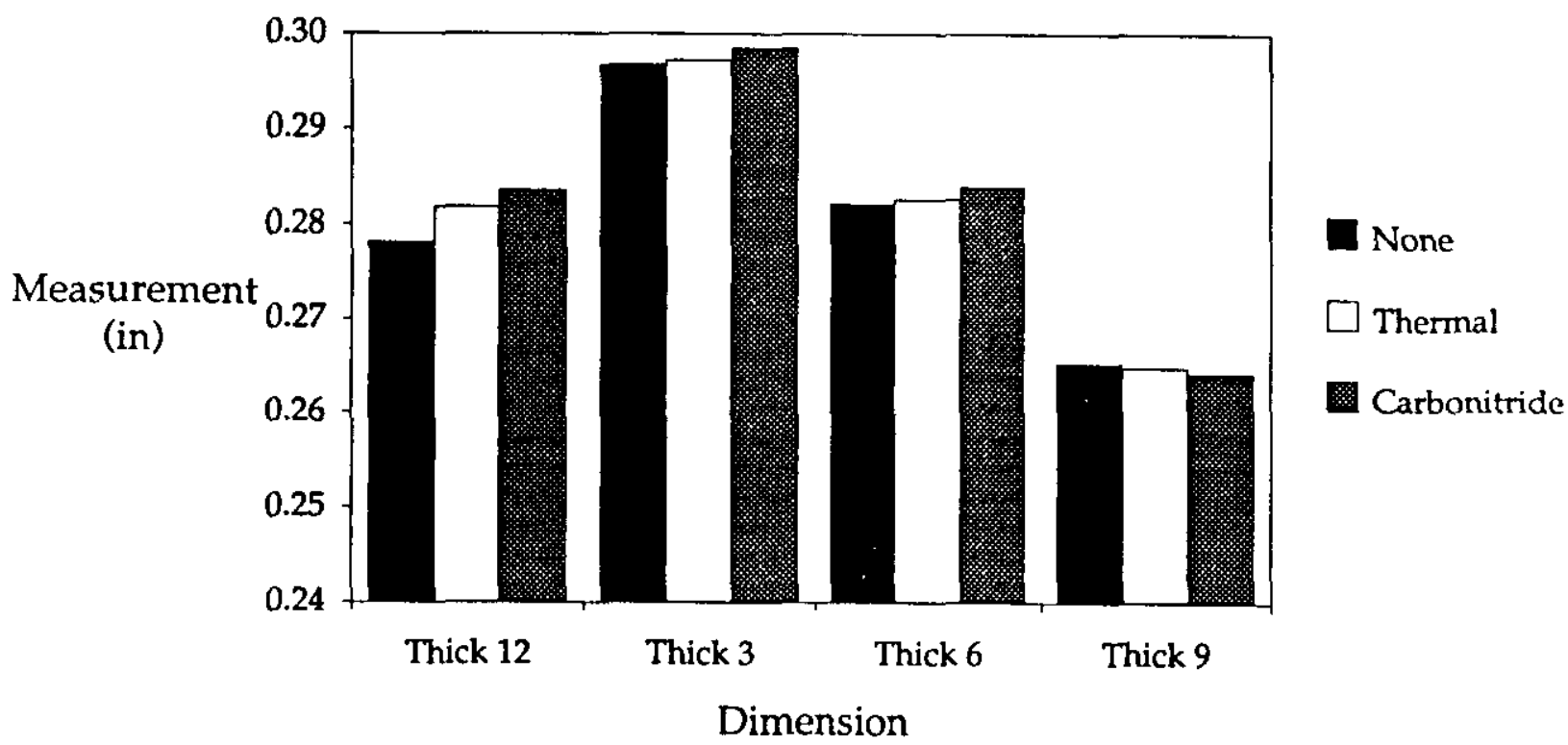

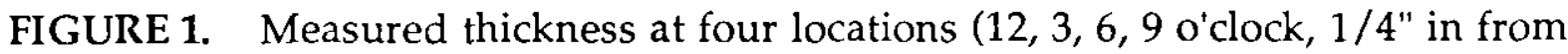
outside) of as-received disk $\mathrm{A}$ and annealed disk B. Both disks are Ti-6-4. Measurements made at beginning, after the thermal treatment alone, and after the Dyna-Blue ${ }^{\mathrm{TM}}$ fluidized bed process. (Compare Fig. 2.) 
Disk C-As Received, No Treatment

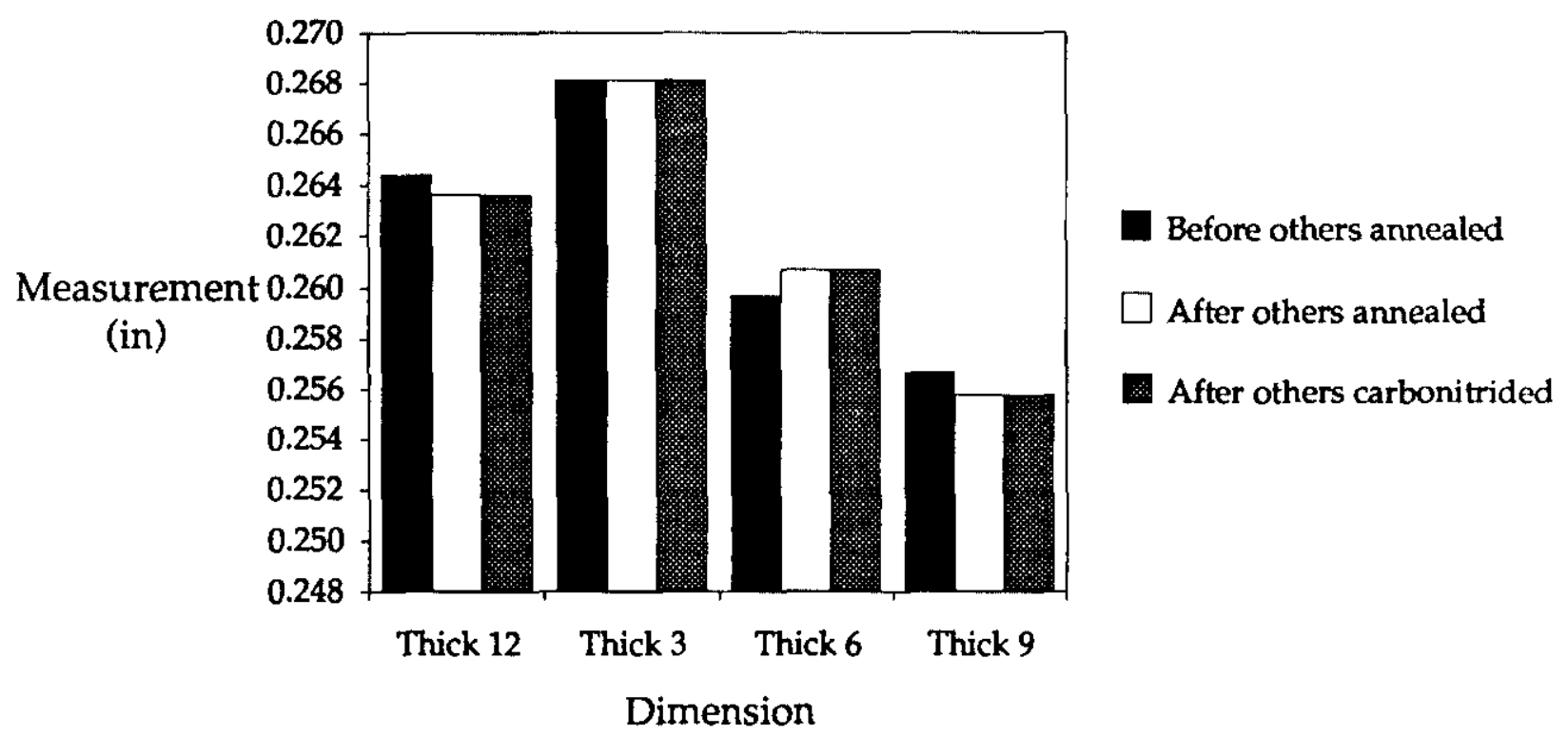

FIGURE 2. Measured thickness at four locations (12, 3, 6, 9 o'clock, 1/4" in from outside) of as-received disk C. Disk is Ti-6-4. Measurements made at same time as other samples, at beginning, after other samples underwent the thermal treatment alone, and after other samples underwent the DynaBlue $^{\mathrm{TM}}$ fluidized bed process. (Compare Fig. 1.) 
Disk A- As Received

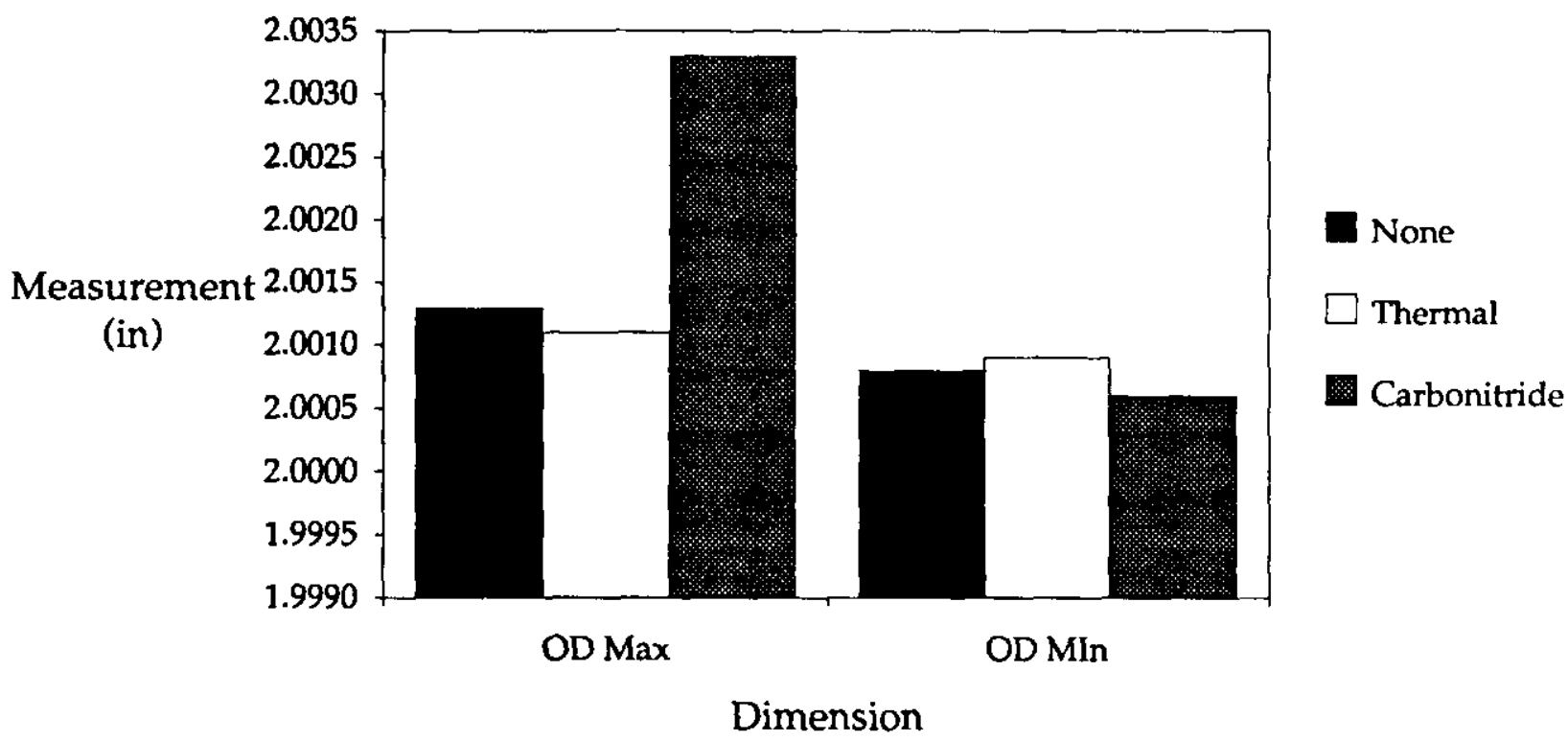

Disk B- Annealed

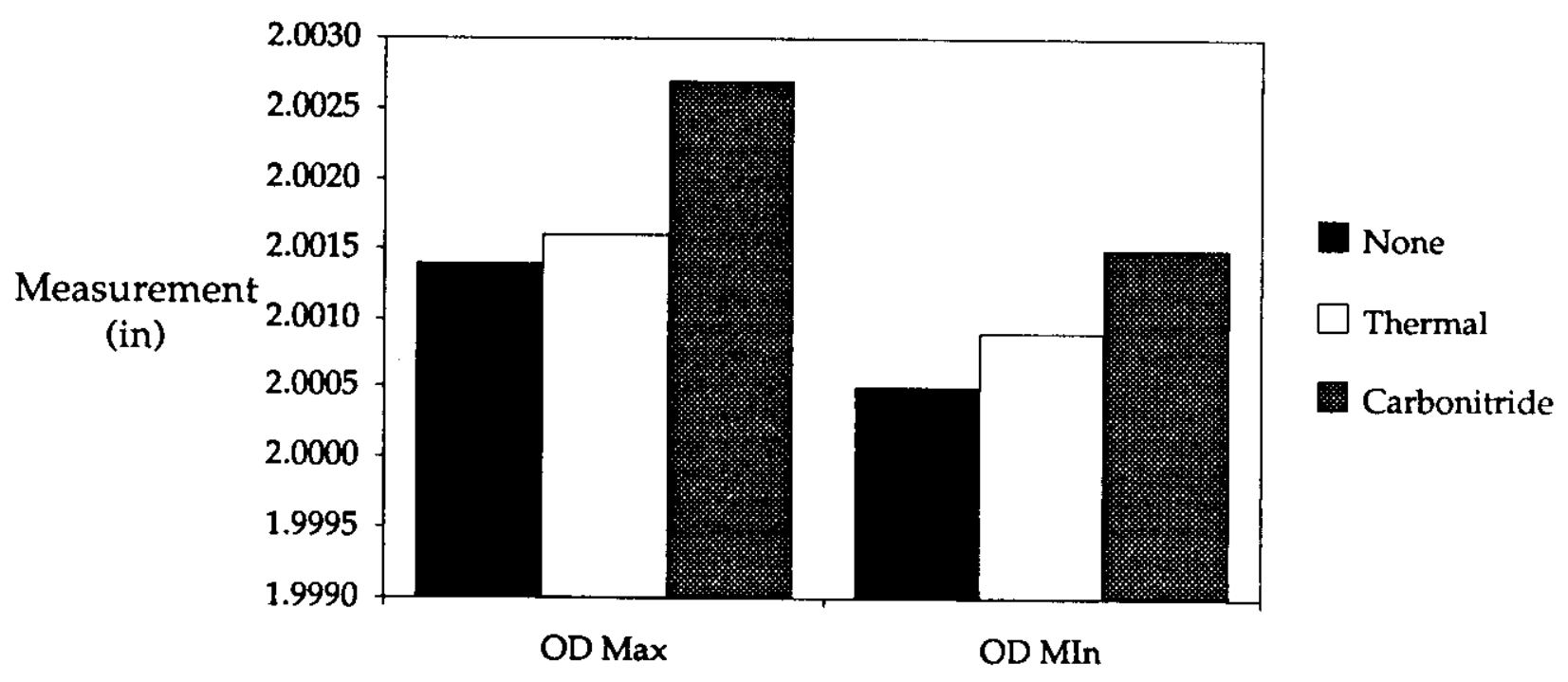

Dimension

FIGURE 3. Measured maximum and minimum outside diameters of as-received disk $A$ and annealed disk B. Both disks are Ti-6-4. Measurements made at beginning, after the thermal treatment alone, and after the Dyna-Blue ${ }^{\mathrm{TM}}$ fluidized bed process. (Compare Fig. 4.) 
Disk C- As Recd., No Treatment

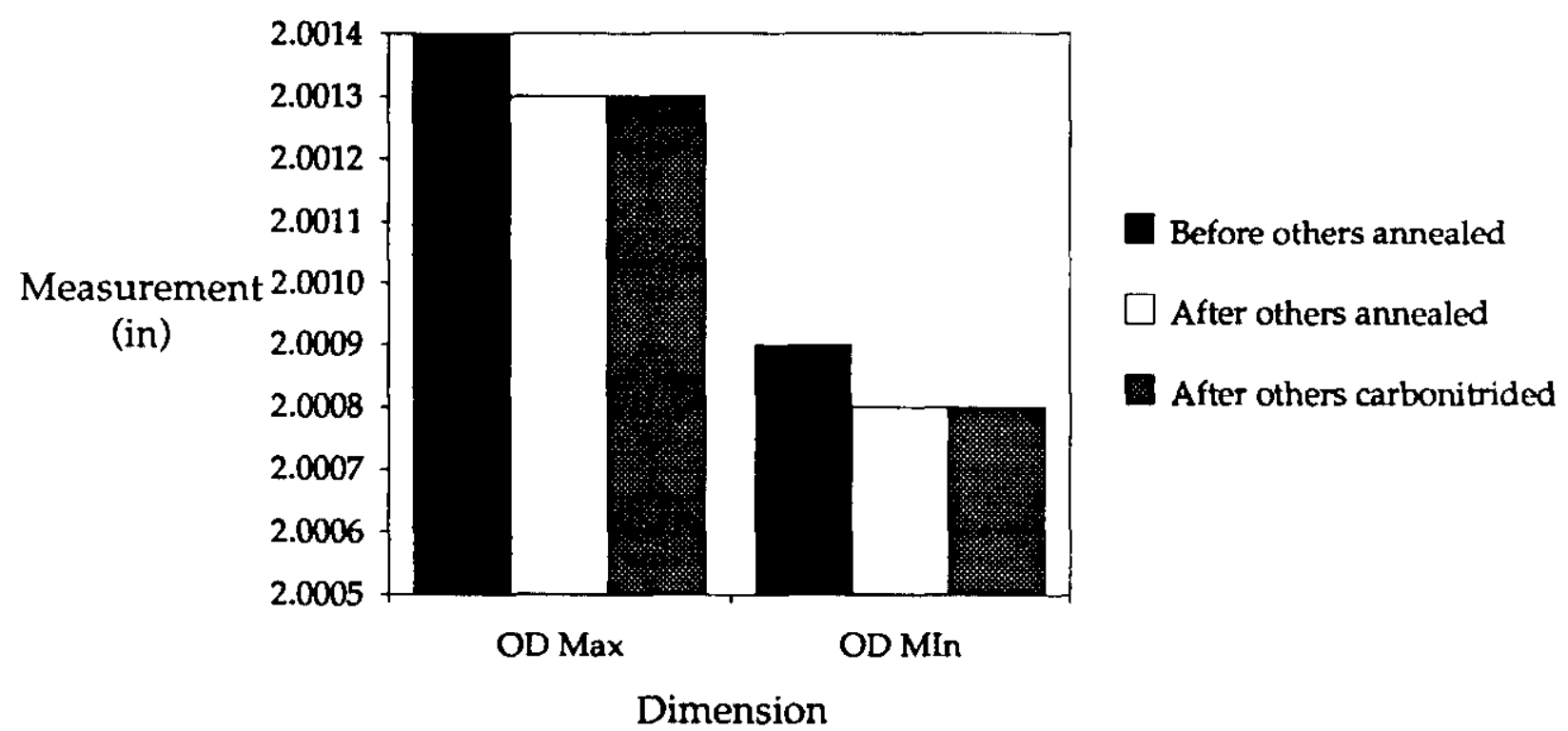

FIGURE 4. Measured maximum and minimum outside diameters of as-received disk C. Disk is Ti-6-4. Measurements made at same time as other samples, at beginning, after other samples underwent the thermal treatment alone, and after other samples underwent the Dyna-Blue ${ }^{\mathrm{TM}}$ fluidized bed process. (Compare Fig. 3.) 
Disk A- As Received

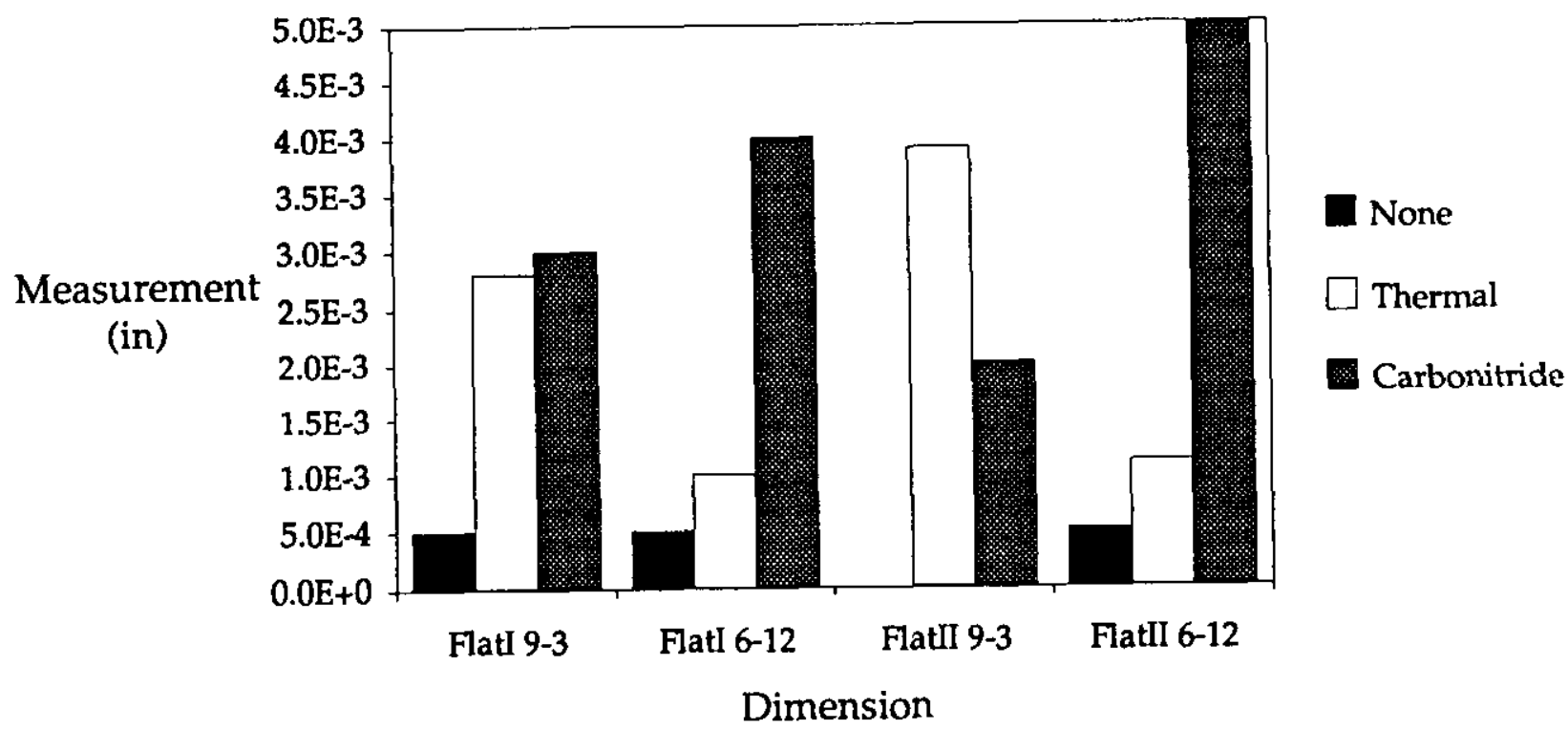

Disk B- Annealed

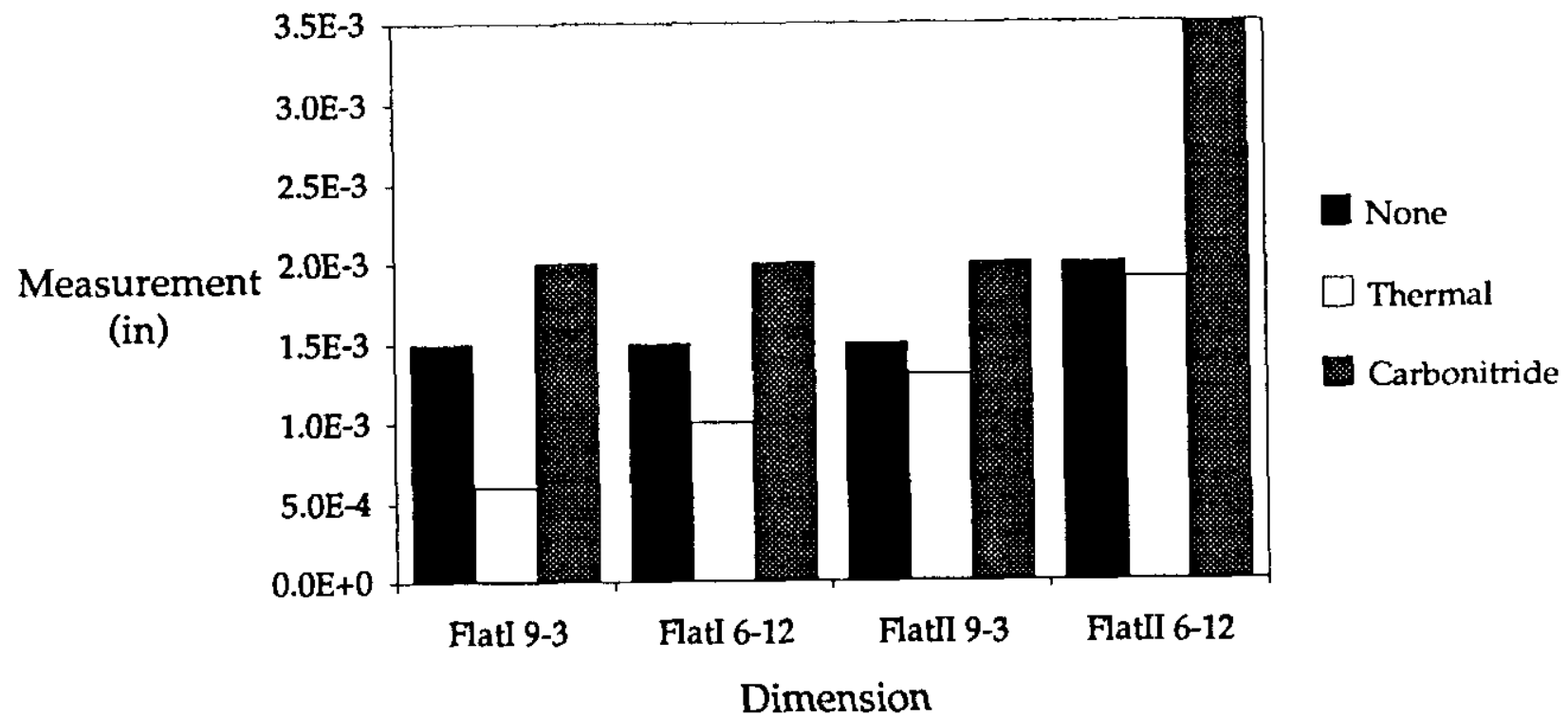

FIGURE 5. Measured flatness of both sides (I and II) in two orthogonal directions (9-3 and 6-12) of as-received disk A and annealed disk B, Total Indicator Reading (TIR). Both disks are Ti-6-4. Measurements made at beginning, after the thermal treatment alone, and after the Dyna-Blue ${ }^{\mathrm{TM}}$ fluidized bed process. (Compare Fig. 6.) 
Disk C- As Recd., No Treatment

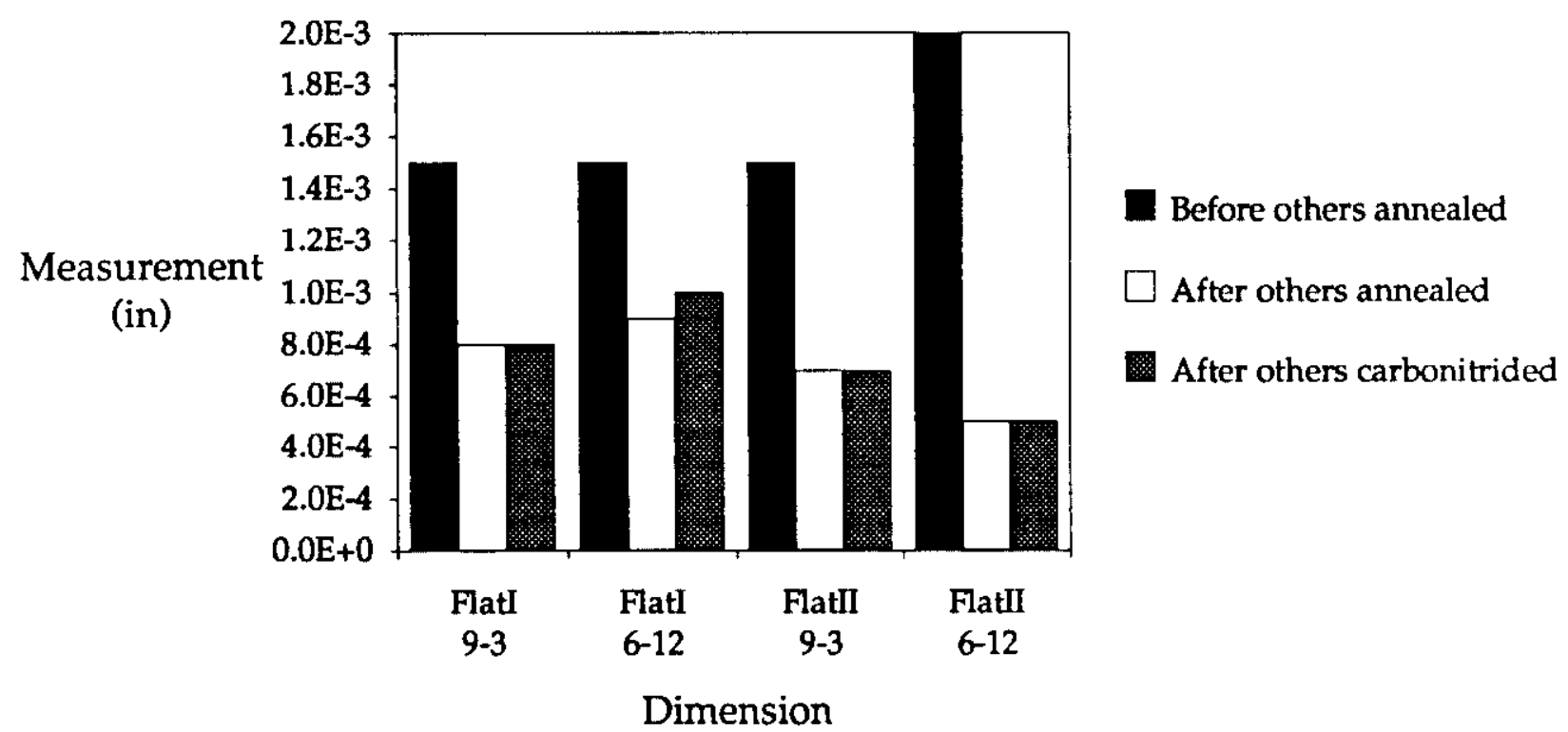

FIGURE 6. Measured flatness of both sides (I and II) in two orthogonal directions (9-3 and 6-12) of as-received disk C. Disk is Ti-6-4. Measurements made at same time as other samples, at beginning, after other samples underwent the thermal treatment alone, and after other samples underwent the Dyna-Blue ${ }^{\mathrm{TM}}$ fluidized bed process. (Compare Fig. 5.) 
Ring A- As Received

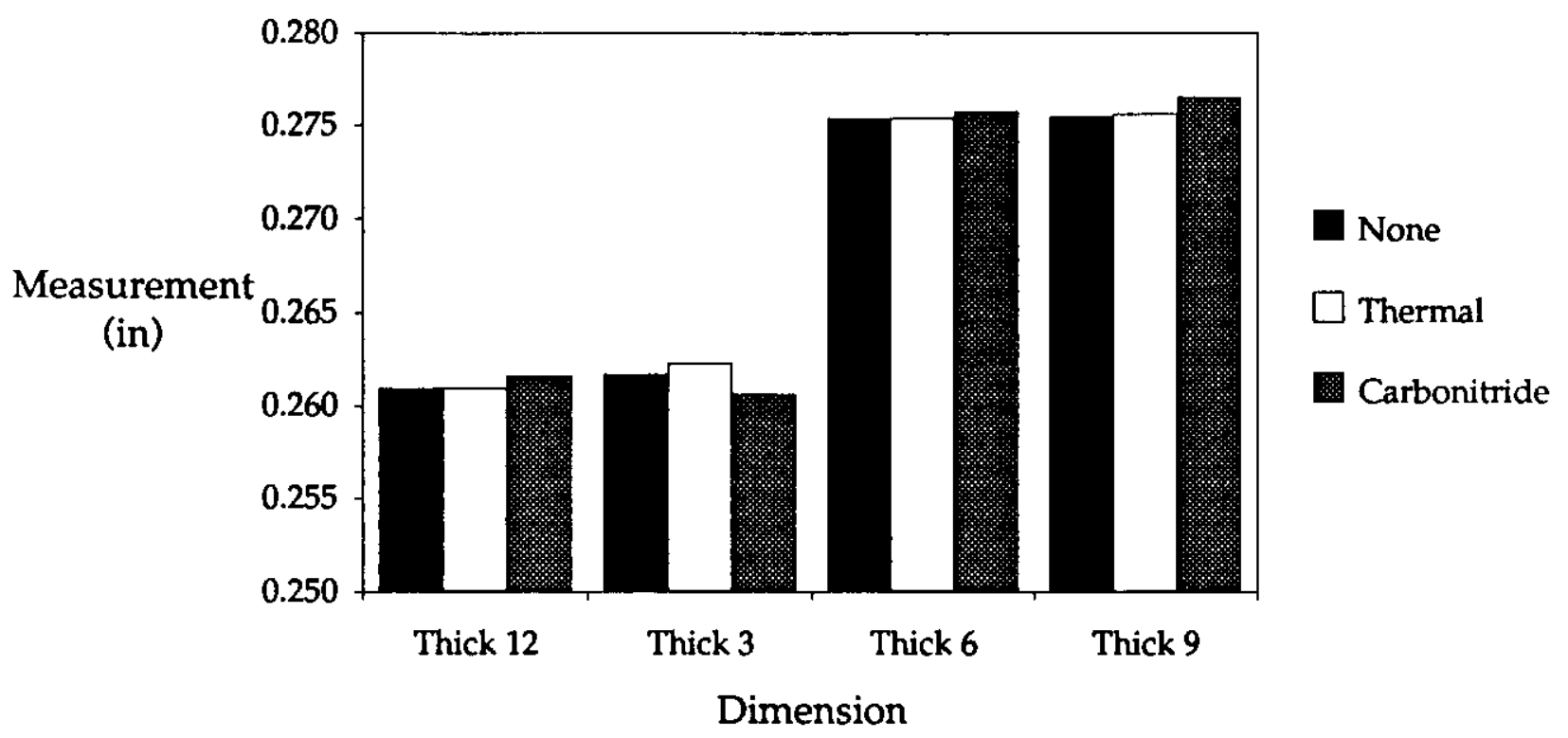

Ring B- Annealed

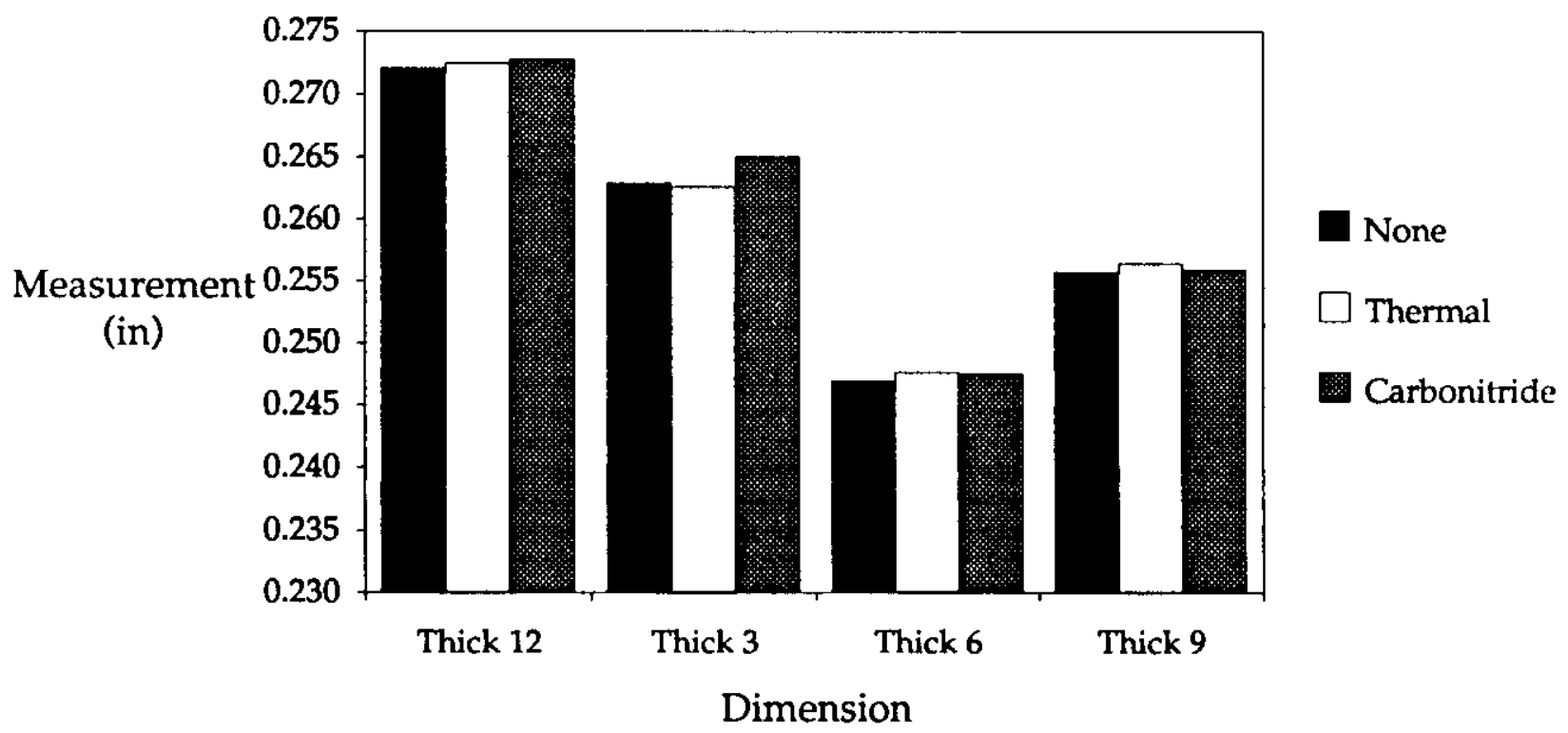

FIGURE 7. Measured thickness at four locations (12, 3, 6, 9 o'clock, 1/4" in from outside) of as-received ring $\mathrm{A}$ and annealed ring $\mathrm{B}$. Both disks are Ti6242S. Measurements made at beginning, after the thermal treatment alone, and after the Dyna-Blue ${ }^{\mathrm{TM}}$ fluidized bed process. 
Ring A- As Received

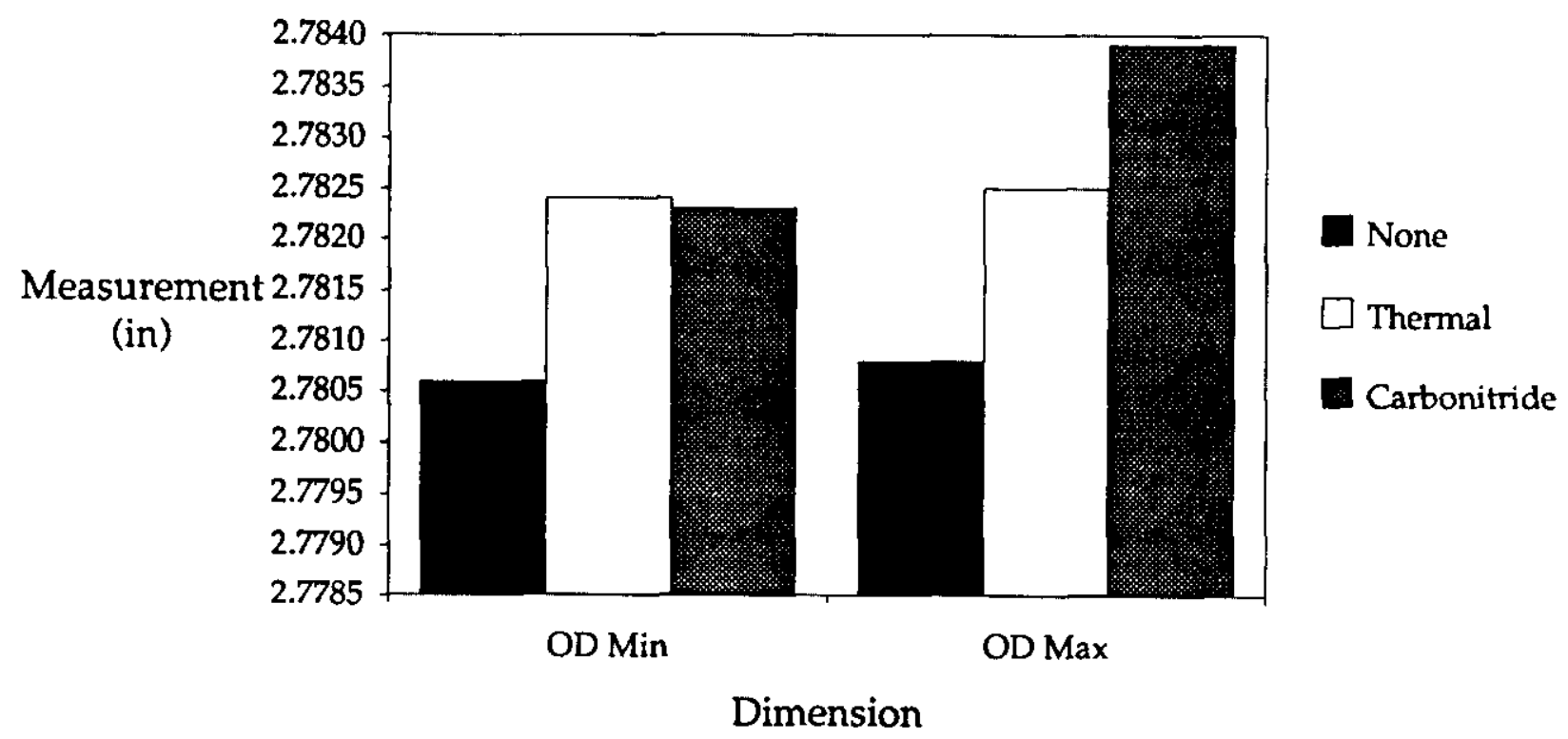

Ring B- Annealed

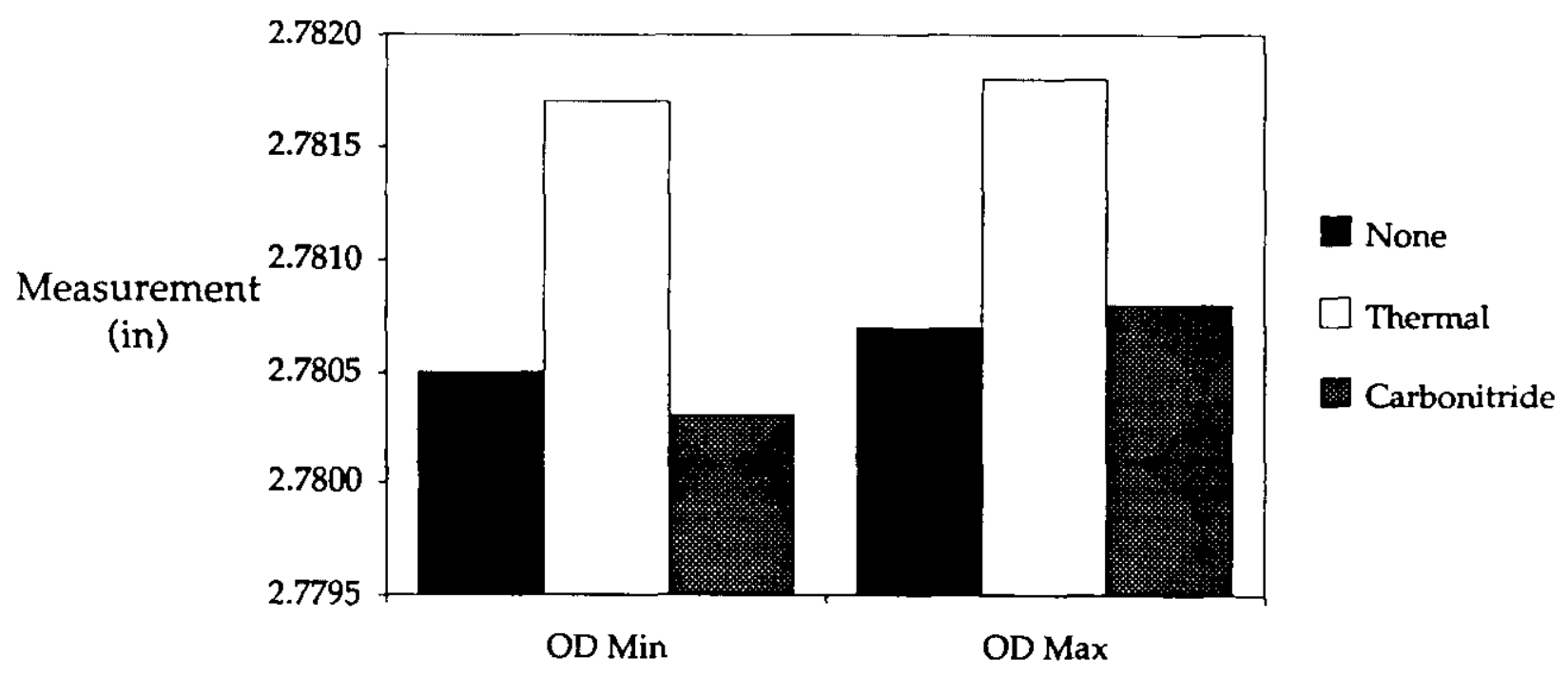

Dimension

FIGURE 8. Measured maximum and minimum outside diameters of as-received ring $A$ and annealed ring B. Both disks are Ti-6242S. Measurements made at beginning, after the thermal treatment alone, and after the Dyna-Blue ${ }^{\mathrm{TM}}$ fluidized bed process. 
Ring A- As Received

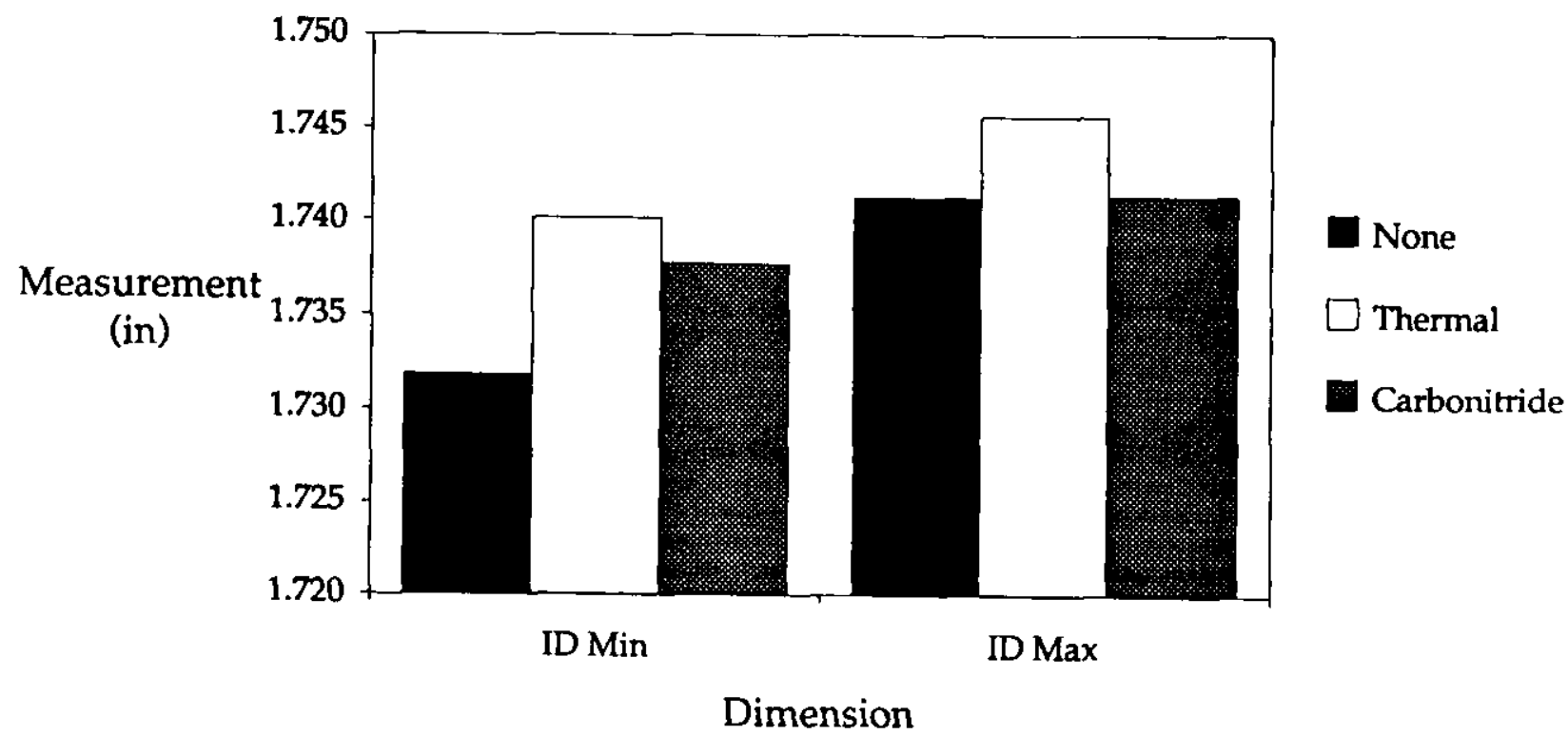

Ring B- Annealed

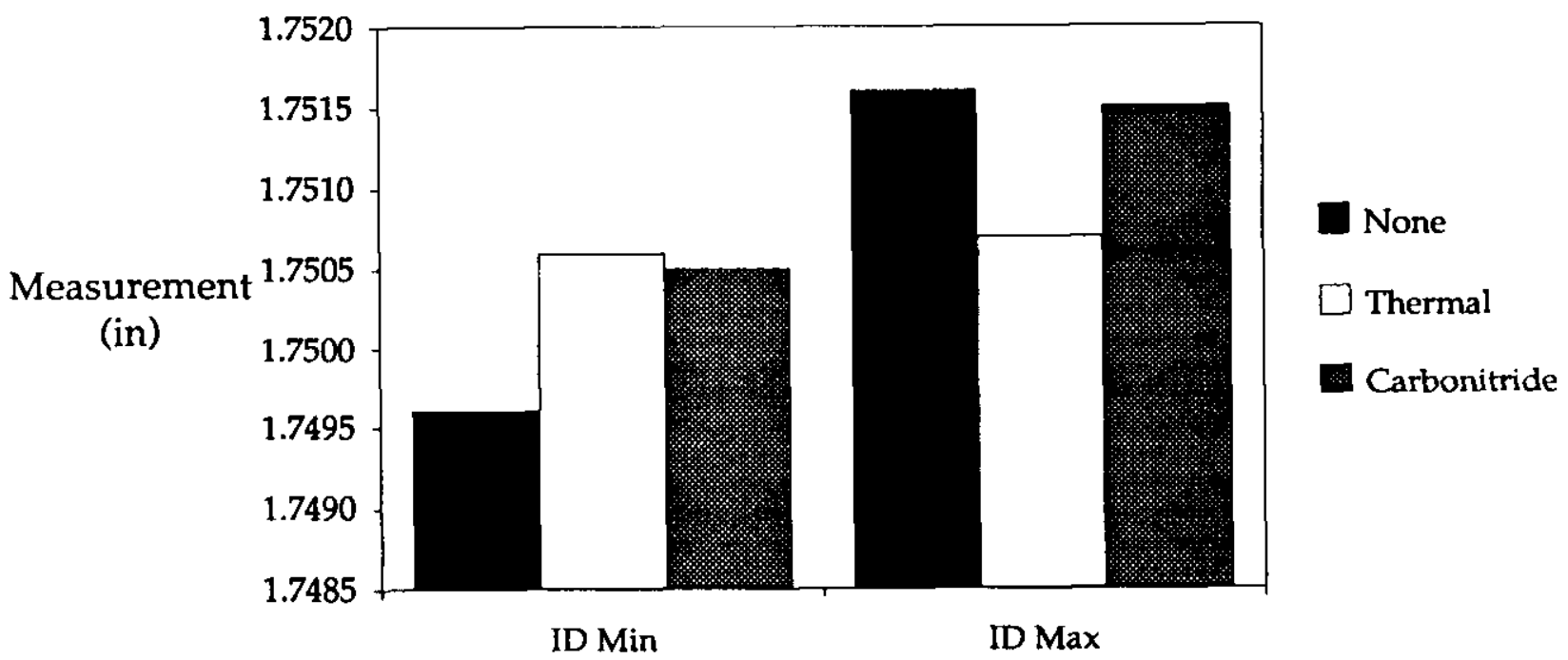

Dimension

FIGURE 9. Measured maximum and minimum inside diameters of as-received ring $A$ and annealed ring B. Both disks are Ti-6242S. Measurements made at beginning, after the thermal treatment alone, and after the Dyna-Blue ${ }^{\mathrm{TM}}$ fluidized bed process. 


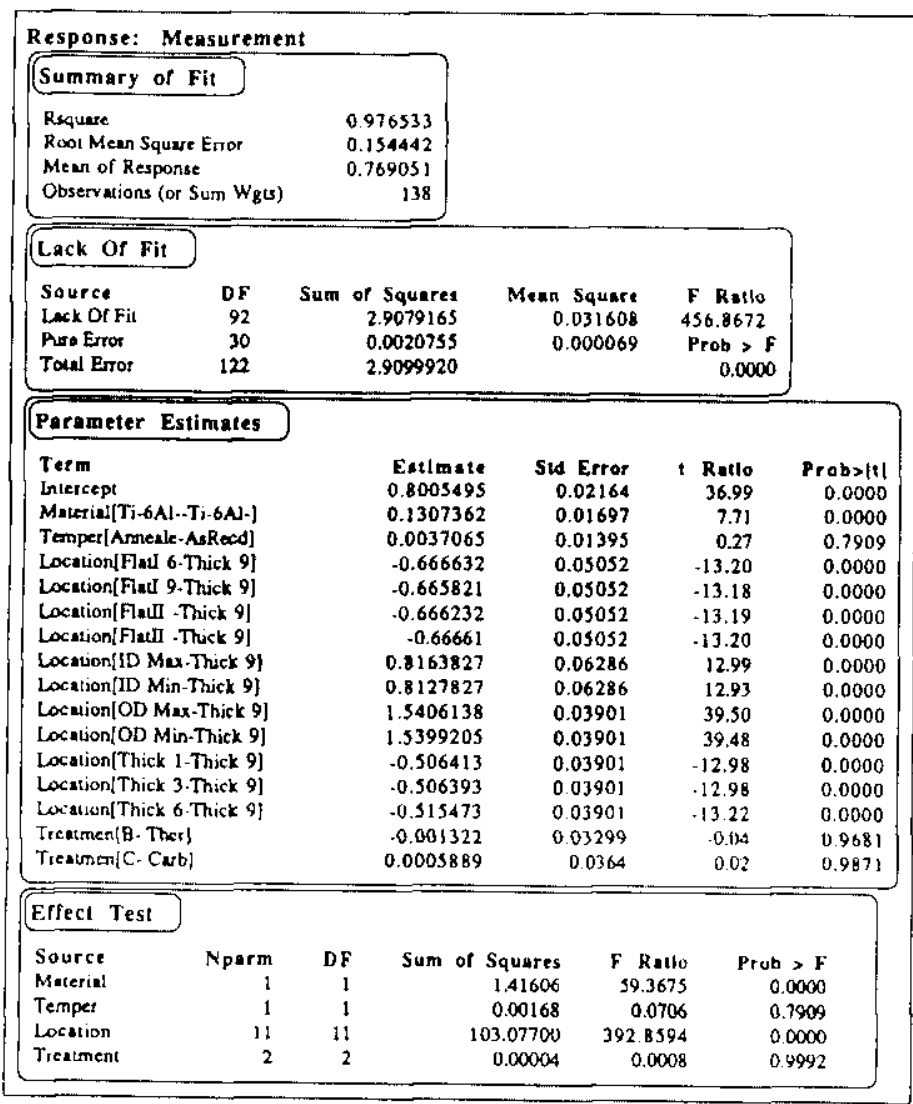

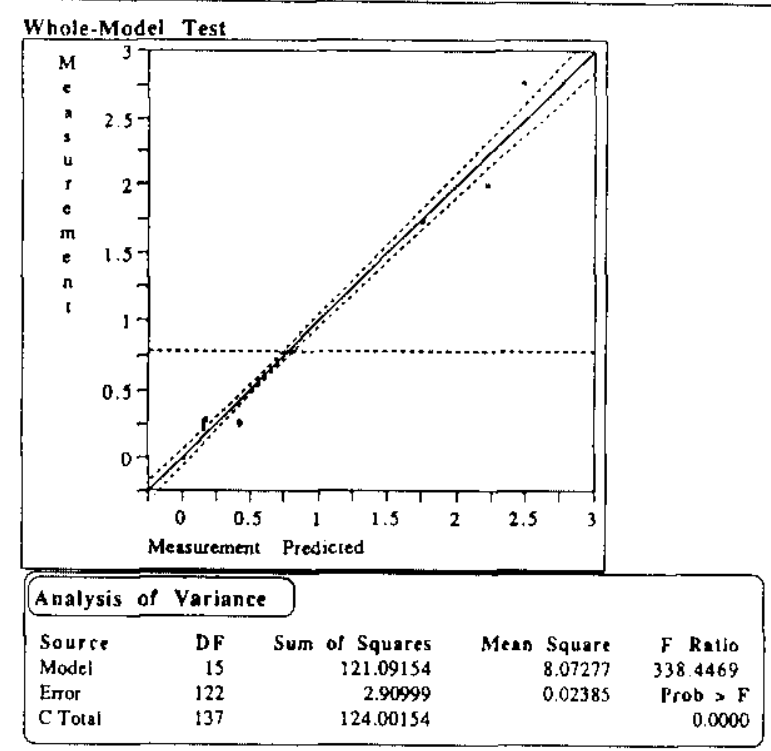

FIGURE 10 a. Output of statistical analysis software JMP for this study. Model consisted of variables Material (Ti-6-4 or Ti-6242S), Treatment (surface), Temper (As Received or Annealed), and Location. Response was the measured dimensions. "Prob $>F$ " under Whole Model Test indicates model is significant. (See also Fig. 10 b.) 

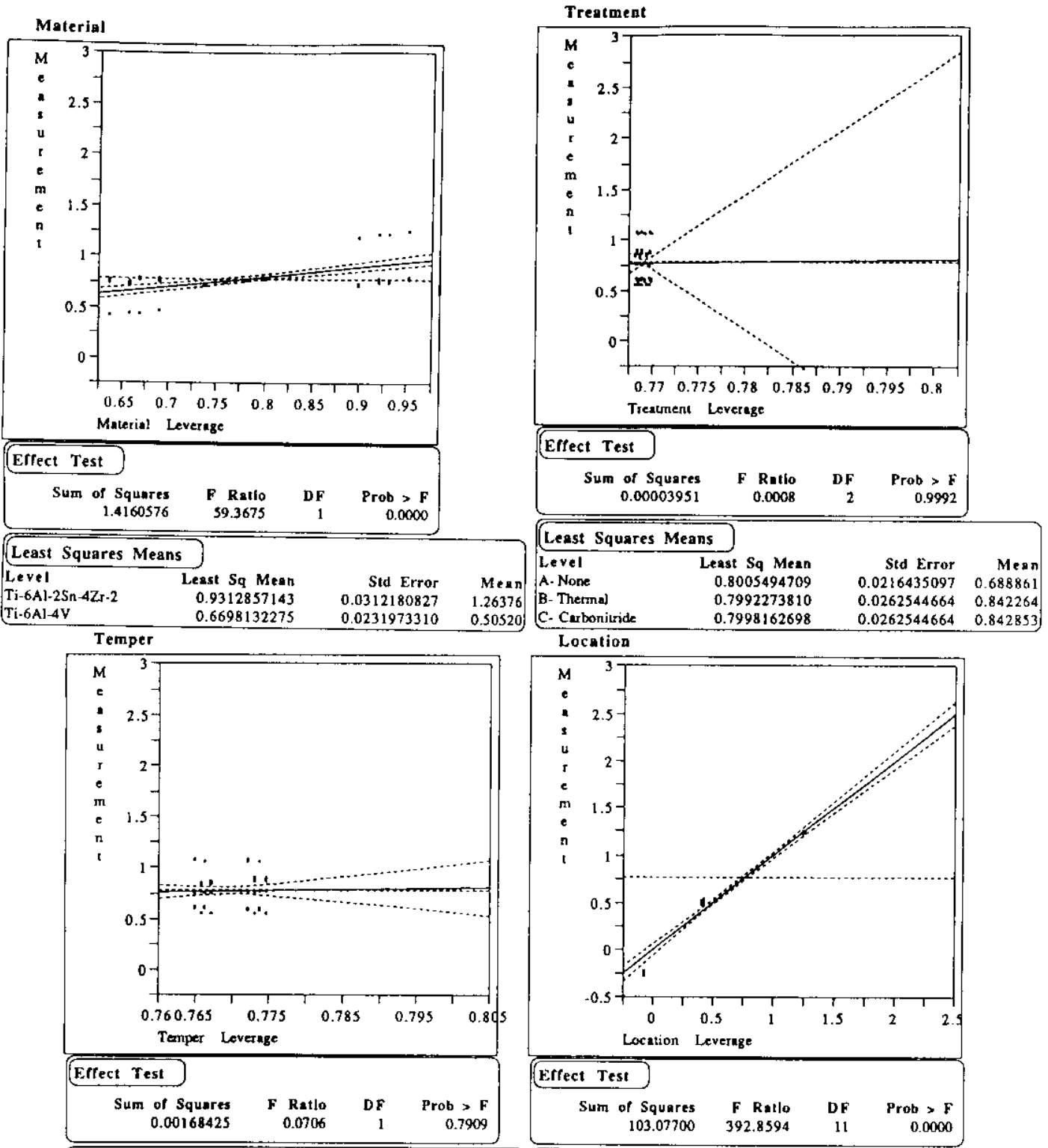

\begin{tabular}{|lrrr|}
\hline Least & Squares Means & & \\
Leve1 & Least Sq Mean & Std Error & Mean \\
Anneale & 0.8042559965 & 0.0285569632 & 0.846607 \\
AsReed & 0.7968429453 & 0.0225944512 & 0.719193 \\
\hline
\end{tabular}

Least Squares Meinns

\begin{tabular}{lrrr} 
Level & Least Sq Menn & Std Error & Mean \\
Find 6-12 & 0.133917372 & 0.0563919869 & 0.00149 \\
Flail 9-3 & 0.134728483 & 0.0563919869 & 0.00230 \\
Flail 6-12 & 0.134317372 & 0.0563919869 & 0.00189 \\
Flacll 9-3 & 0.133939594 & 0.0563919869 & 0.00151 \\
ID Max & $1.6 ! 6932187$ & 0.0671207058 & 1.74698 \\
ID Min & 1.613332187 & 0.0671207058 & 1.74338 \\
OD Max & 2.341163298 & 0.0430688196 & 2.31373 \\
OD Min & 2.340469965 & 0.0430688196 & $\mathbf{2 . 3 1 3 0 3}$ \\
Thick 12 & 0.294136631 & 0.0430688196 & 0.26670 \\
Thick 3 & 0.294156631 & $\mathbf{0 . 0 4 3 0 6 8 8 1 9 6}$ & 0.26672 \\
Thick 6 & $\mathbf{0 . 2 8 5 0 7 6 6 3 1}$ & 0.0430688196 & 0.25764 \\
Thick 9 & $\mathbf{0 . 2 8 4 4 2 3 2 9 8}$ & 0.0430688196 & 0.25699 \\
\hline
\end{tabular}

FIGURE $10 \mathrm{~b}$. See Fig. 10 a. Large values of "Prob>F" in Treatment and Temper indicates no significant effect of surface treatment or initial temper on measured dimensions. 

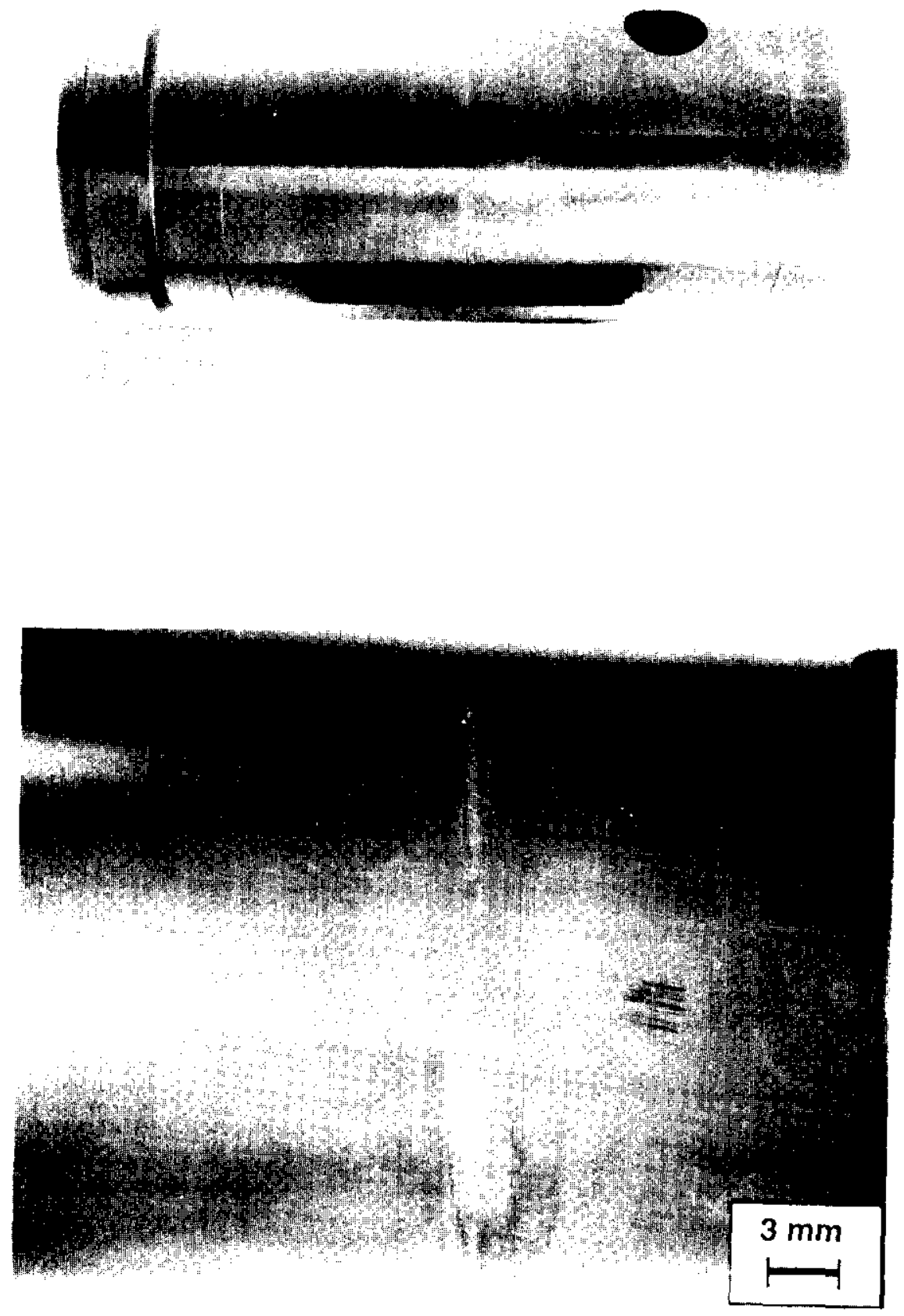

FIGURE 11. Photograph of shot sleeve. Mark on side underneath blue-black surface film, appeared after return of shot sleeve from surface coating. 
THIS PAGE INTENTIONALLY LEFT BLANK EXCEPT FOR THIS MESSAGE 
THIS PAGE INTENTIONALLY LEFT BLANK EXCEPT FOR THIS MESSAGE 
Distribution for WSRC-TR-93-474:

\begin{tabular}{llll} 
V.L. Skidmore & $723-\mathrm{A}$ & L. Romanowski & 723-A \\
M. Hart & $723-\mathrm{A}$ & D.T. Rankin & $773-\mathrm{A}$ \\
W.I. Lewis & $773-\mathrm{A}$ & J.P Veldman & $723-\mathrm{A}$ \\
T.L. Capeletti & $773-41 \mathrm{~A}$ & T.J. French & $730-\mathrm{A}$ \\
P.S. Hebert & $723-\mathrm{A}$ & MTS Files (J.M. Gantz) & $773-\mathrm{A}$ \\
J.D. Cohen & $730-\mathrm{A}$ & Technical Information & $703-43 \mathrm{~A}$ \\
& \multicolumn{3}{r}{ Management (4 copies) }
\end{tabular}

